Proc. Estonian Acad. Sci. Geol., 1998, 47, 3, 141-157

\title{
VOLKHOV STAGE IN NORTH ESTONIA AND SEA LEVEL CHANGES
}

\author{
Tõnu MEIDLA, Leho AINSAAR, and Oive TINN
}

Institute of Geology, University of Tartu, Vanemuise 46, EE-2400 Tartu, Estonia; e-mail: tmeidla@math.ut.ee

Received 18 March 1998, in revised form 20 May 1998

\begin{abstract}
Changes in ostracode diversity and mineralogical composition of insoluble residue were studied to document environmental and biological events in the Volkhov succession of North Estonia. The most prominent bioevents occur in the basal and middle parts of the stage. The higher quartz/K-feldspar ratio in silt fraction of insoluble residue of the early Volkhov carbonates is interpreted as indicative of extensive reworking and redeposition of Cambrian-earliest Ordovician terrigenous formations. The data are discussed in the context of different models of sea level changes.
\end{abstract}

Key words: Ordovician, Volkhov Stage, ostracodes, sea level.

\section{INTRODUCTION}

In the mid-Arenig, during the Billingen-Volkhov time, normal-marine carbonate sedimentation started in the eastern part of the Baltoscandian Palaeobasin, for the first time during its history. This transgressive episode has been interpreted differently with respect to smaller-scale sea level fluctuations, based on the variation of the sediment supply, the faunal succession, and palaeogeography. The sedimentary sequence of North Estonia, which probably characterizes the shallowest part of the palaeobasin, is supposed to have been most sensitive to sea level changes. The aim of the present study was to recognize the environmental and biotic events in the Volkhov succession of North Estonia and to reveal the relationships between the events and the detailed sea level curves elaborated for different parts of the Baltoscandian Palaeobasin (Nielsen, 1992, 1995; Dronov et al., 1998). 


\section{PALAEOGEOGRAPHICAL SETTING}

The Baltoscandian Palaeobasin, which was situated approximately at $35-45^{\circ}$ southern palaeolatitudes during the Arenig (Torsvik et al., 1996), is characterized by a regular distribution pattern of the main lithofacies. This large-scale zonation, introduced as facies zones by Männil (1966) and later developed into a concept of confacies belts by Jaanusson (1976, fig. 7), comprises two areas, southern and northern, within the today's territory of Estonia. In southern Estonia predominantly argillaceous-carbonate sedimentation took place in the conditions of lower ramp. The area is, together with western Latvia and northwestern Lithuania, regarded as a part of the Central Baltoscandian Confacies Belt. The North Estonian Confacies Belt lies in the marginal area of the palaeobasin. It is characterized by discontinuous sedimentation, probably referring to a middleupper ramp zone near fair-weather wave base. Differences in sedimentation and environmental parameters within the confacies belts are expressed in the distribution of most fossil groups in the Viru and Harju series of Estonia. Preliminary ostracode data suggest similar differences for the Ontika Subseries, although generally faunal differentiation is less distinct there (Männil, 1966).

The Volkhov age is known as an episode of a rise in faunal diversity, although in part it is apparently an effect of more favourable conditions of preservation for shelly fossil groups. In this interval the succession of graptolites, conodonts, and lingulate brachiopods is complemented with diverse assemblages of trilobites, brachiopods, ostracodes, and many other groups, generally regarded as typical of the Ordovician.

\section{STRATIGRAPHY}

The Volkhov Stage, roughly corresponding to the "Glauconite Limestone" by Schmidt $(1879,1881)$ and subsequent authors, forms a lithologically distinctive unit in the sections of the North Estonian Klint and nearby river valleys. It is the oldest stage in the Ordovician of Estonia where the carbonate sediments are prevailing. Biostratigraphically, the Volkhov Stage is defined by the trilobite succession ranging from the base of the Megistaspis polyphemus Zone to the top of the Megistaspis limbata Zone (Männil, 1966; Männil \& Meidla, 1994).

Distinction of three substages in the Volkhov Stage, introduced by Lamansky (1905) for the St Petersburg Region, was originally also based on trilobite zonation. However, in Estonia microfossils are reported to be more abundant in the stage (Sarv, 1959, 1963; Viira, 1974; Nõlvak \& Grahn, 1993; Meidla, 1997), whereas macrofossils are rare (Mägi, 1984, 1990). The data on trilobite distribution, which originally served as a basis for defining the substages of the Volkhov Stage in Estonia, remained almost unrevised for a considerable time (Öpik, 1937; Männil, 1966; see Aru, 1990 and Rõõmusoks, 1997 for a review). 
In Scandinavia a tripartite biostratigraphical subdivision of the Volkhov Stage based on the trilobite succession was proposed by Tjernvik (1956). He also suggested that the tripartite subdivision of the Volkhov Stage in Scandinavia was not consistent with the East Baltic usage (Tjernvik, 1980). Recently the differences between the East Baltic and Scandinavian substages were summarized by Nielsen (1995, fig. 32; see Meidla, 1997 for a review).

The currently used lithological tripartite subdivision of the Volkhov Stage was adopted for Estonia by Orviku $(1958,1960)$ in agreement with the substage concept of Lamansky (1905). In modern terms the stage is nearly equivalent to the Toila Formation (Fm.) in North Estonia. The formation represents a complicated stratum of various partly dolomitized glauconitiferous limestones resting on sandstones of the Leetse Fm. The basal part of the Toila Fm., the Päite Member $(\mathrm{Mb}$.) of the Billingen Stage, is separated from the main part of the formation by a smooth discontinuity surface with "amphora-like borings" (Orviku, 1960) or the so-called Püstakkiht (Orviku, 1961; also known as Steklo, Blommiga Bladet, Flowery Sheet). In North Estonia the Volkhov age part of the Toila Fm. is subdivided into five members (Saka, Telinõmme, Künnapõhja, Lahepera, and Kalvi Mbs. - see Fig. 1). The lower part of the Sillaoru Fm. (Pada Mb.), locally resting on the Toila Fm., has also been tentatively assigned to the Volkhov Stage (Orviku, 1960).

Recently, Volkhov conodont successions of Scandinavia were studied in detail by Stouge (1989) and Löfgren (1995). They give a thorough analysis of relations between the trilobite and conodont zones proposing conodonts as another key group for subdividing the Arenig in Baltoscandia. The Estonian substages have also been redefined in terms of conodont record (e.g. Männil, 1990).

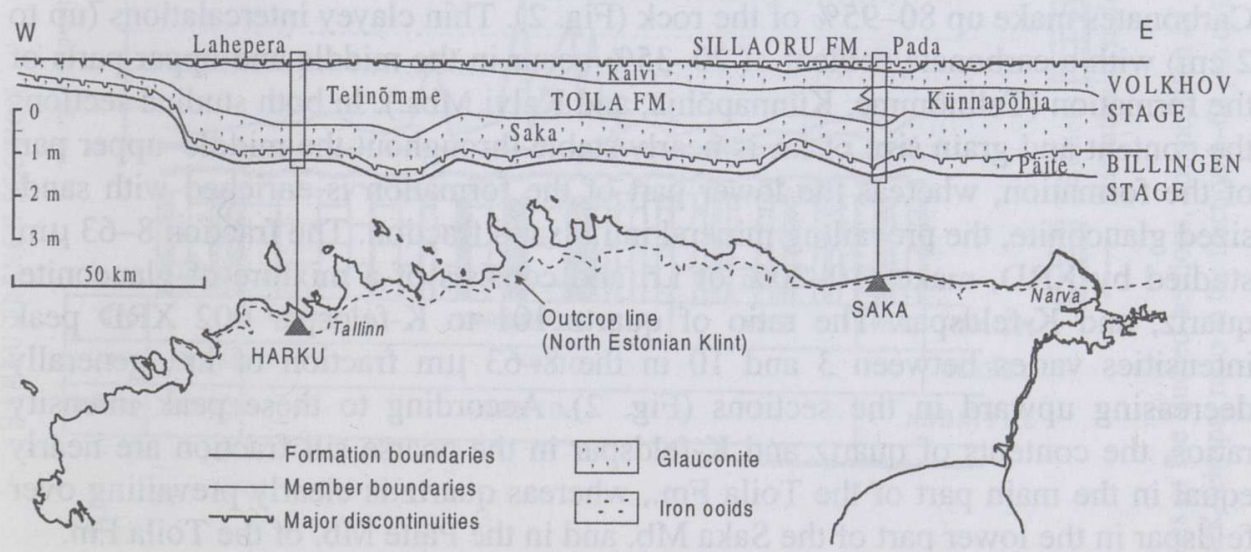

Fig. 1. Cross-section of the Toila Formation along the North Estonian Klint (after Orviku, 1960 and Meidla, 1997) and the location of the studied sections. 


\section{MATERIAL AND METHODS}

In North Estonia two sections of the Toila Fm. were studied (Fig. 1). The Saka klint section is situated on the coastline in northeastern Estonia, $2 \mathrm{~km}$ west of the village of Saka. The Harku trench section is located near Tallinn, $1.5 \mathrm{~km}$ south of Lake Harku, south of the Tallinn-Keila road. In both studied sections the Volkhov Stage has a fairly similar thickness, but the overlying Kunda Stage is considerably thicker at Saka. The succession of local members is different in these sections. At Saka the Toila Fm. is represented (from the base) by the Päite, Saka, Telinõmme, Künnapõhja, and Kalvi Mbs., in the Harku section by the Päite, Saka, Telinõmme, and Lahepera Mbs. In both sections the succession of the Volkhov Stage is assumed to be nearly complete, with no essential parts (substages) missing.

Samples from both sections were subjected to sedimentological and mineralogical analysis. The carbonate component of the samples (with initial weight of $50 \mathrm{~g}$ ) was dissolved in diluted (3.5\%) hydrochloric acid. Insoluble residue (i.r.) was fractionated by gravity sedimentation and sieving into the following fractions: $<2,2-8,8-63$, and $>63 \mu \mathrm{m}$. Qualitative and semiquantitative mineralogical composition of the $8-63 \mu \mathrm{m}$ fraction was analysed by X-ray diffraction (XRD) using the DRON-0.5 diffractometer (Mn-filtered Fe- $K \alpha$ radiation). For the ostracode record, the sets of bed-by-bed samples were processed using a treatment with sodium hyposulphite, with subsequent picking of the shells under the binocular microscope (see Meidla, 1996 for details).

\section{COMPOSITION OF CARBONATE ROCKS AND CHANGES IN TERRIGENOUS INFLUX}

The Toila Fm. is represented by glauconitic limestones and secondary dolomites. Carbonates make up $80-95 \%$ of the rock (Fig. 2). Thin clayey intercalations (up to $2 \mathrm{~cm}$ ) with a carbonate content of $20-35 \%$ occur in the middle and upper parts of the formation (Telinõmme, Künnapõhja, and Kalvi Mbs.). In both studied sections the content and grain size of i.r. is nearly stable throughout the middle-upper part of the formation, whereas the lower part of the formation is enriched with sandsized glauconite, the prevailing mineral in i.r. sand fraction. The fraction $8-63 \mu \mathrm{m}$, studied by XRD, makes $10-20 \%$ of i.r. and consists of a mixture of glauconite, quartz, and K-feldspar. The ratio of quartz 101 to K-feldspar 002 XRD peak intensities varies between 3 and 10 in the $8-63 \mu \mathrm{m}$ fraction of i.r., generally decreasing upward in the sections (Fig. 2). According to these peak intensity ratios, the contents of quartz and K-feldspar in the coarse silt fraction are nearly equal in the main part of the Toila Fm., whereas quartz is clearly prevailing over feldspar in the lower part of the Saka Mb. and in the Päite Mb. of the Toila Fm.

The Sillaoru Fm. is represented by oolitic limestones. The carbonate content is $60-90 \%$, in clayey intercalations $25-35 \%$. The sand fraction $(0.063-2.0 \mathrm{~mm})$ of i.r. (3-60\% of i.r.) consists mainly of iron (goethitic) ooids, only a sample from the Pada Mb. contains some glauconite as well. The fraction $8-63 \mu \mathrm{m}$ of i.r. $(10-15 \%$ 


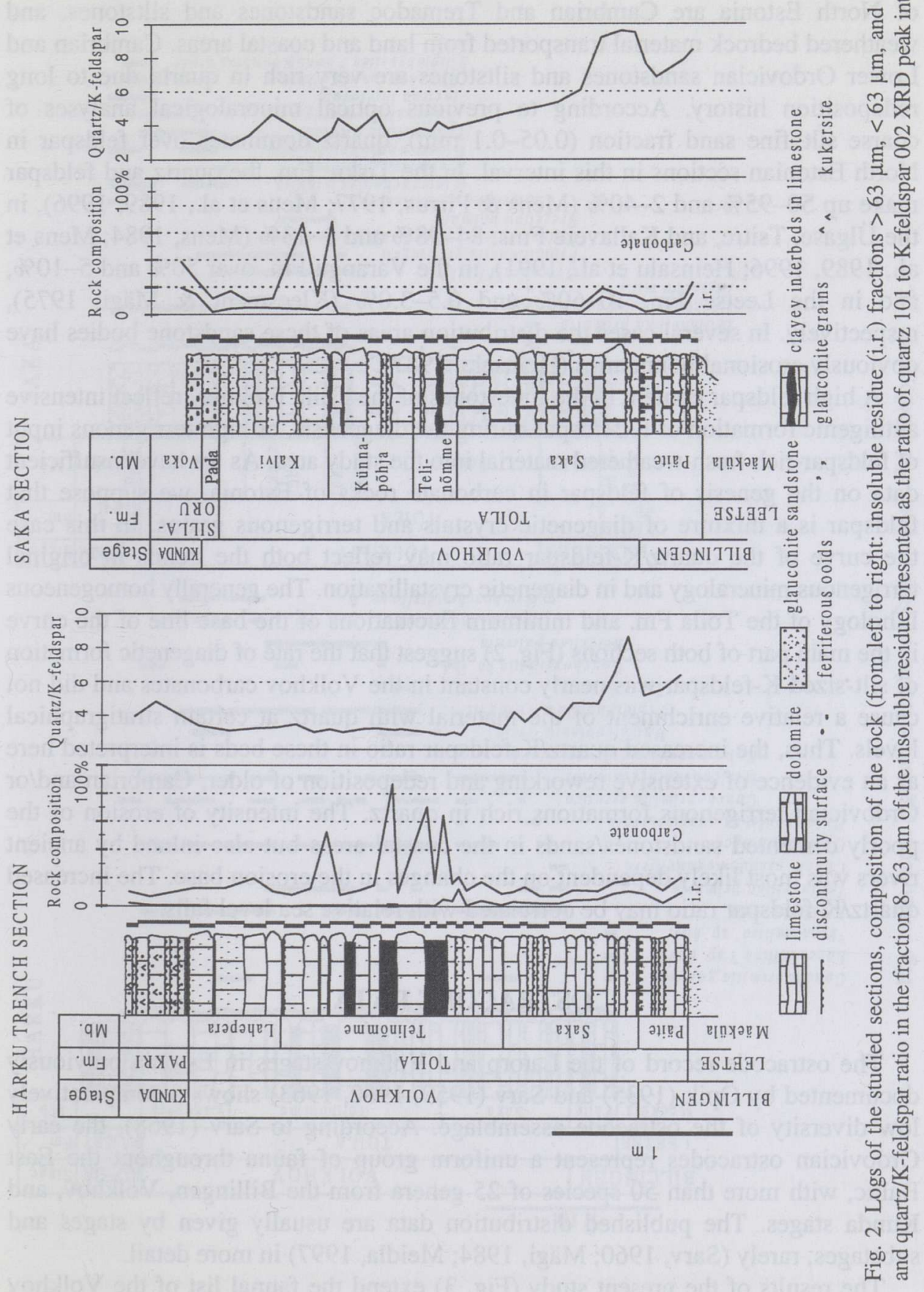


of i.r.) contains goethite, quartz, and K-feldspar; the quartz/K-feldspar ratio is similar to that in the upper part of the Toila Fm.

The possible sources of terrigenous material in early Ordovician carbonates of North Estonia are Cambrian and Tremadoc sandstones and siltstones, and weathered bedrock material transported from land and coastal areas. Cambrian and Lower Ordovician sandstones and siltstones are very rich in quartz due to long redeposition history. According to previous optical mineralogical analyses of coarse silt-fine sand fraction $(0.05-0.1 \mathrm{~mm})$, quartz dominates over feldspar in North Estonian sections in this interval. In the Tiskre Fm. the quartz and feldspar make up 50-95\% and 2-40\% (Mens \& Pirrus, 1977; Mens et al., 1989, 1996), in the Ülgase, Tsitre, and Kallavere Fms. 84-98\% and 1-13\% (Mens, 1984; Mens et al., 1989, 1996; Heinsalu et al., 1991), in the Varangu Fm. over 50\% and 5-10\%, and in the Leetse Fm. 10-60\% and 0.5-3.0\% (Kleesment \& Mägi, 1975), respectively. In several cases the distribution areas of these sandstone bodies have obviously erosional boundaries (Heinsalu, 1987).

A high feldspar content in the limestones of the Toila Fm. may reflect intensive authigenic formation of $\mathrm{K}$-feldspar during the diagenesis, or high terrigenous input of feldspar-rich fresh-weathered material into the study area. As we have insufficient data on the genesis of feldspar in carbonate rocks of Estonia, we suppose that feldspar is a mixture of diagenetic crystals and terrigenous grains. In this case the curve of the quartz/K-feldspar ratio may reflect both the trends in original terrigenous mineralogy and in diagenetic crystallization. The generally homogeneous lithology of the Toila Fm. and minimum fluctuations of the base line of the curve in the main part of both sections (Fig. 2) suggest that the rate of diagenetic formation of silt-sized K-feldspar was nearly constant in the Volkhov carbonates and did not cause a relative enrichment of the material with quartz at certain stratigraphical levels. Thus, the increased quartz/K-feldspar ratio in these beds is interpreted here as an evidence of extensive reworking and redeposition of older, Cambrian and/or Ordovician terrigenous formations rich in quartz. The intensity of erosion of the poorly cemented sandstones/sands in the coastal areas but also inland by ancient rivers was most likely dependent on the changes in the erosion base. The increased quartz/K-feldspar ratio may be correlated with relative sea level falls.

\section{OSTRACODE DATA}

The ostracode record of the Latorp and Volkhov stages in Estonia previously documented by Öpik $(1935)$ and Sarv $(1959,1960,1963)$ shows a comparatively low diversity of the ostracode assemblage. According to Sarv (1968), the early Ordovician ostracodes represent a uniform group of fauna throughout the East Baltic, with more than 50 species of 25 genera from the Billingen, Volkhov, and Kunda stages. The published distribution data are usually given by stages and substages, rarely (Sarv, 1960; Mägi, 1984; Meidla, 1997) in more detail.

The results of the present study (Fig. 3) extend the faunal list of the Volkhov Stage. It is dominated by palaeocopes which are mainly represented by the 

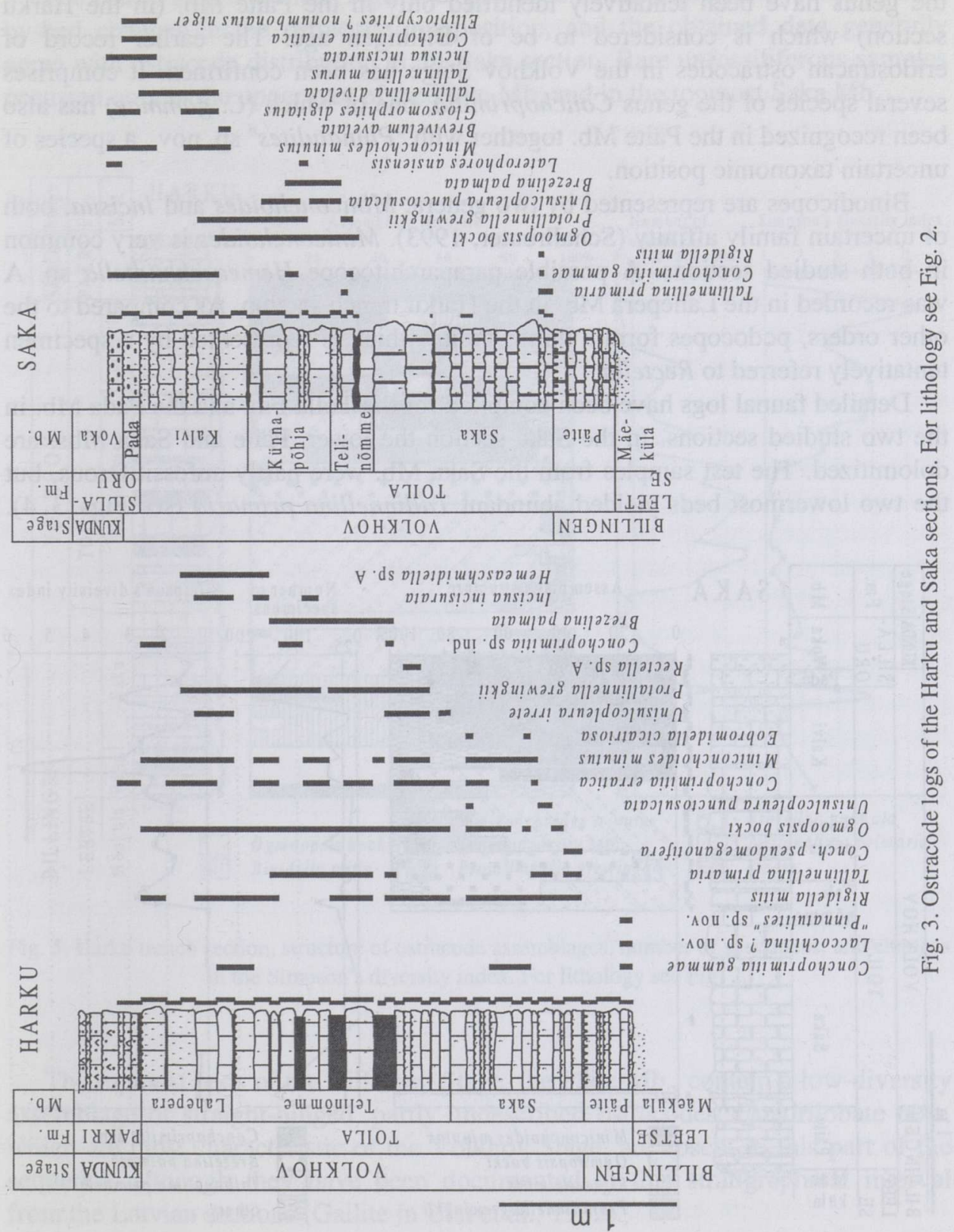
superfamily Hollinacea. This group comprises species of 8 genera of the families Tetradellidae, Ctenonotellidae, and Tvaerenellidae. The eurychilinacean genus Laccochilina has been reported as one of the common genera in the Volkhov Stage of the Estonian sequence. Yet, in the studied sections the representatives of the genus have been tentatively identified only in the Päite Mb. (in the Harku section) which is considered to be of Billingen age. The earlier record of eridostracan ostracodes in the Volkhov Stage has been confirmed. It comprises several species of the genus Conchoprimitia, one of which (C. gammae) has also been recognized in the Päite Mb. together with "Pinnatulites" sp. nov., a species of uncertain taxonomic position.

Binodicopes are represented by two genera, Miniconchoides and Incisua, both of uncertain family affinity (Schallreuter, 1993). Miniconchoides is very common in both studied sections. A possible paraparchitocope Hemeaschmidtella sp. A was recorded in the Lahepera Mb. in the Harku trench section. As compared to the other orders, podocopes form a minor group which is represented by a specimen tentatively referred to Rectella.

Detailed faunal logs have been compiled for the Toila Fm. and the Pada Mb. in the two studied sections. In the Saka section the lower, Päite and Saka Mbs. are dolomitized. The test samples from the Saka Mb. were partly unfossiliferous, but the two lowermost beds yielded abundant Tallinnellina primaria (see Figs. 3, 4).

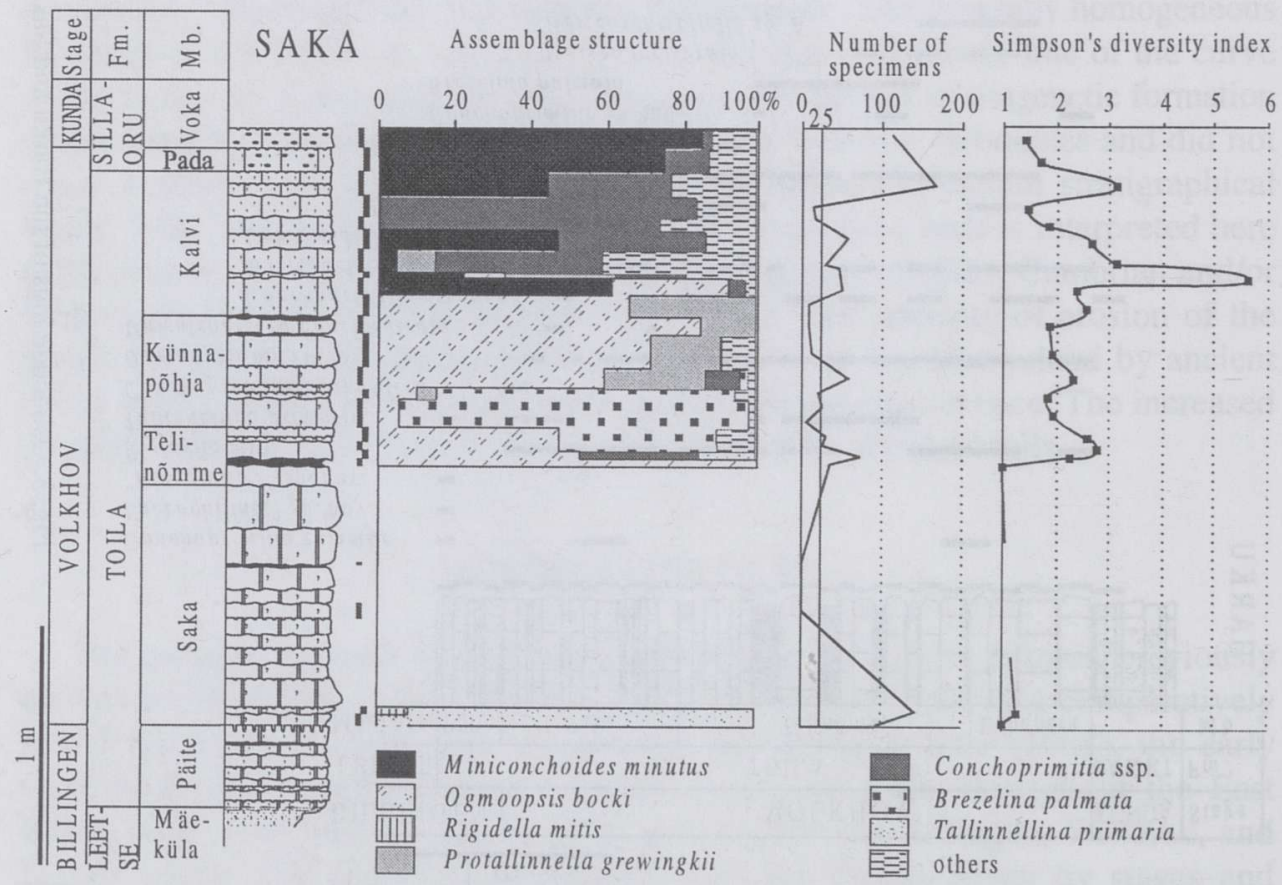

Fig. 4. Saka section, structure of ostracode assemblages, number of specimens, and changes in the Simpson's diversity index. For lithology see Fig. 2. 
A continuous faunal log begins in the lower part of the Telinõmme $\mathrm{Mb}$. in this section. A bed-by-bed sampling revealed several ostracode assemblages of comparatively stable composition and structure in that part of the sequence (Fig. 4; see also Meidla \& Ainsaar, 1996 for a review).

The Harku trench section (Figs. 3, 5) provided a nearly complete record of bedby-bed changes in the ostracode composition, and the obtained data generally agree with ostracode distribution in the Saka section. Rare unfossiliferous samples occurred only in the upper part of the Päite Mb. and in the topmost Saka Mb.

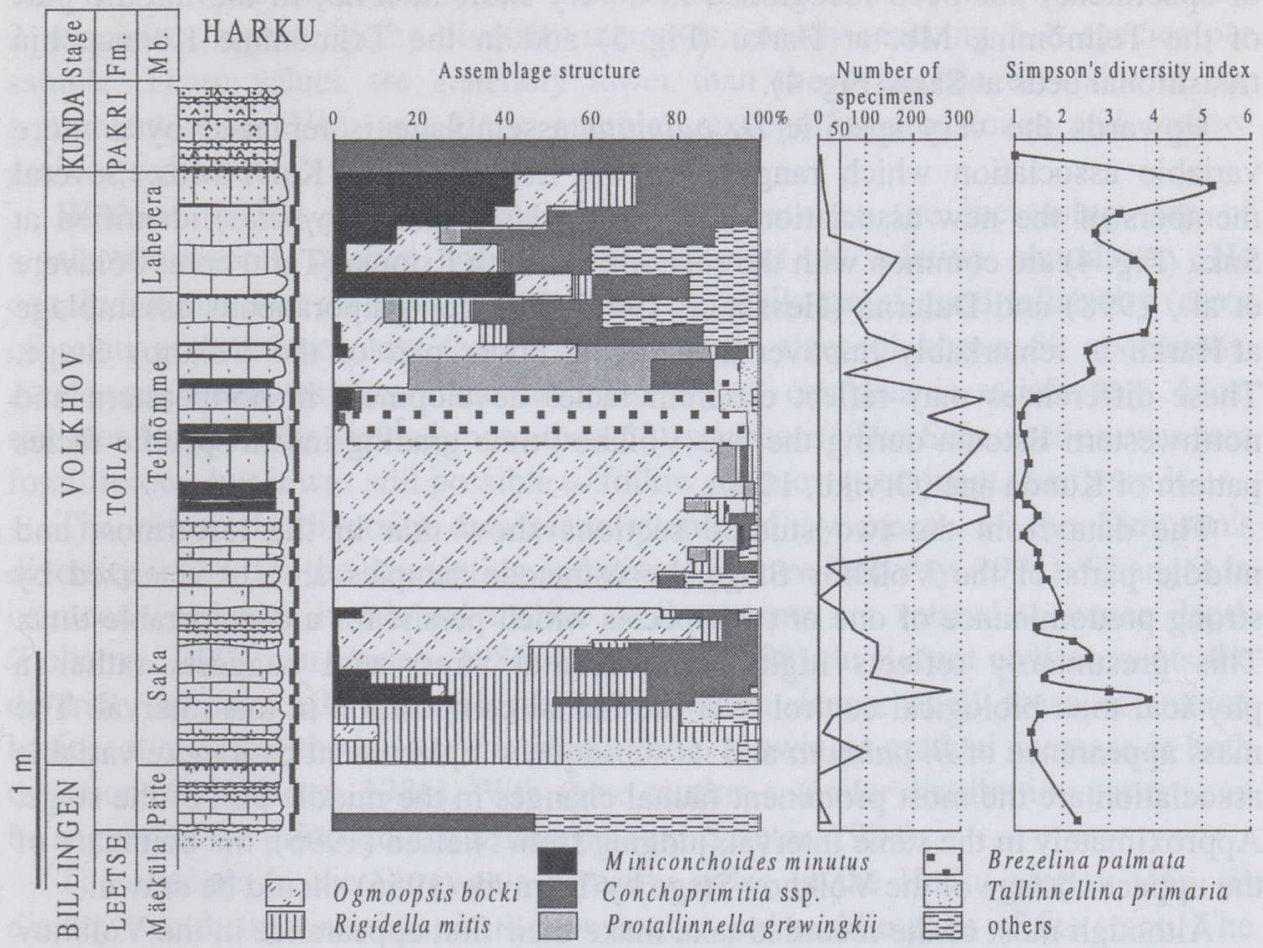

Fig. 5. Harku trench section, structure of ostracode assemblages, number of specimens, and changes in the Simpson's diversity index. For lithology see Fig. 2.

The topmost beds of the Billingen Stage, the Päite Mb., contain a low-diversity assemblage of straight-hinged, partly undescribed ostracodes. Quadrilobate taxa, which are most characteristic of the Volkhov Stage, are absent in this part of the sequence, although they have been documented in this stratigraphical interval from the Latvian sections (Gailite in Ulst et al., 1982).

The lowermost Saka Mb. above the Püstakkiht is already characterized by a low-diversity assemblage of quadrilobate hollinomorphs, Rigidella mitis and Tallinnellina primaria. In both sections an increased quartz/K-feldspar ratio in silt 
fraction of i.r. has been recorded on this level (see Fig. 2), possibly referring to a regressive episode.

In the middle part of the Saka Mb. a new assemblage appears. It is dominated by Ogmoopsis bocki and contains several ostracode taxa formerly not recorded in the Volkhov Stage in Estonia (Miniconchoides and Unisulcopleura).

The ostracode record of the lower part of the Telinõmme Mb. is dominated by Ogmoopsis bocki and it generally coincides with that of the upper part of the Saka $\mathrm{Mb}$. The mid-Volkhov ostracode succession shows great similarity in both studied sections. Very high abundance of Brezelina palmata (60-90\% of the total number of specimens) has been recognized in a very short interval, in the middle part of the Telinõmme $\mathrm{Mb}$. at Harku (Fig. 5) and in the Telinõmme-Künnapõhja transitional beds at Saka (Fig. 4).

Upwards the very specific $B$. palmata assemblage is replaced by a more variable association which ranges into the Lahepera and Kalvi Mbs. Several members of the new association (Glossomorphites, Elliptocyprites) identified at Saka (Fig. 4) are common with the sections of South Estonia (Tartu core: Põldvere et al., 1998) and Dalarna (Hessland, 1949). The contemporaneous assemblage at Harku is remarkably impoverished in the upper part of the Volkhov Stage. These differences may reflect different facies development in northeastern and northwestern Estonia during the late Volkhov time grading into a specific facies pattern of Kunda age (Orviku, 1960).

The data from the two studied sections show that in the lowermost and middle parts of the Volkhov Stage the ostracode samples are characterized by strong predominance of one or two species which persist for a considerable time. This presumably reflects high environmental stress and suggests rather a physical than biological control over the faunal composition in this interval. The mass appearance of $B$. palmata and its subsequent replacement by a more variable association are the most prominent faunal changes in the middle part of the stage. Approximately in the same interval, judging from Nielsen (1995), the boundary of the upper substage of the Volkhov Stage by Tjernvik (1956) should be drawn.

Although most of the recorded taxa make their first appearance in the Volkhov Stage, the poor knowledge of the distribution of species in the lower part of the stage still complicates the usage of the presence and absence data for biostratigraphical purposes. There are several ways for interpreting the ostracode composition and faunal dynamics in the Volkhov succession. Most of the recognized taxa have been recorded, except for North Estonia, also in other parts of the palaeobasin (Thorslund, 1940; Hessland, 1949; Ulst et al., 1982; Sidaravičiene, 1992, 1996; Põldvere et al., 1998) or from the erratic material (Schallreuter, 1988, 1989, 1994; etc.). However, the data set is too fragmentary for summarizing the faunal dynamics for the entire palaeobasin or for its relevant part.

The modes of life and habitats of individual early Palaeozoic ostracode taxa are still largely unknown. The relationship between the external features of ostracode carapace and particular habitats, even in Recent environments, is doubtful. In Recent ostracodes the morphology of the carapace seems to be more closely 
correlated to the mode of locomotion, which enables us to distinguish between swimming and crawling taxa (Henningsmoen, 1965). Many palaeocope ostracodes are supposed to be bottom-dwelling swimmers, but their relationship with the depth and type of substratum is poorly known yet.

The ostracode abundance and diversity pattern is greatly variable in the studied sections. The obtained data set comprises altogether 21 ostracode species identified in the studied sections, which shows a considerably higher diversity than known earlier for North Estonia. The number of ostracode specimens varied in the fossiliferous samples from the Saka and Harku sections, but the diversity was low. In the Päite and lower Saka members the samples contain usually 2-4 species, higher up the diversity increases, mostly reaching 5-8 species per sample. These values are generally lower than the ostracode diversity in the equivalent upper Viru and Harju samples, except for mudstones and coarsegrained sediments.

Watkins (1979) analysed the relationship between the increasing size of a palaeontological sample and the measurement of relative abundance. He concluded that data on relative abundance of fossils are of good reliability (error of relative abundance less than $3 \%$ ) at sample sizes of above 50 specimens. Analogous estimates show that the reliability of our data is satisfactory. Most samples from Harku yielded more than 50 specimens. The Saka section was less fossiliferous, but it was still possible to follow the most prominent change in it.

The ostracode diversity data were quantified by means of the Simpson's diversity index (for the description and discussion see Pokorny, 1971). Changes in ostracode diversity in normal marine environments are related to water depth (Pokorny, 1971; van Harten, 1986; Brouwers, 1988). In Recent environments the diversity of ostracode assemblages is highest in deeper shelf areas of marine basins, at or below the base of the photic zone, showing a gradual decrease in both directions (van Harten, 1986). With some caution a similar distribution pattern can be suggested for Palaeozoic assemblages (e.g. Siveter, 1984).

The changes in the Simpson's diversity index in the Harku section (Fig. 5) display two distinct minima, in the lowermost and middle parts of the stage. The elevated values are recorded in the lower part of the stage (with a continuous decrease upwards) and in its upper part. The data from the fossiliferous part of the Saka section also show relatively lower values in the middle part of the stage and higher values in the upper part, but the diversity curve is in obvious correlation with the number of specimens on certain levels (Fig. 4).

\section{SEA LEVEL CHANGES}

For the eastern Baltic area, the earliest detailed model of sea level changes of Volkhov age was proposed by Lamansky (1905) and mainly confirmed by subsequent authors. Männil (1966) characterizes the Ontika epoch as that of a developing transgression. He reported the similarity of the sea level conditions 
during the Billingen and early Volkhov ages, with a regression at the Billingen/Volkhov boundary, and tied this boundary to Piistakkiht, a characteristic surface recognizable over a distance of 1200-1500 km (Männil, 1966). The appearance of nodular, argillaceous limestones and marls in the middle Volkhov was interpreted by him as an indicator of a developing transgression. It was followed by a new shallowing during late Volkhov age which terminated as a period of nondeposition during the Hunderum (early Kunda age).

This model, with the deepest-water episode in the mid-Volkhov, has generally been accepted for Estonia and extrapolated to the whole eastern part of the Baltoscandian Palaeobasin. Männil (1966, p. 108) proposed also a different way of development for the easternmost part of the palaeobasin, suggesting the deepest-water conditions during late Volkhov age for the vicinity of the Volkhov River, Russia. However, the latter viewpoint was not supported by recent investigations by Dronov et al. (1998).

A detailed sea level curve, based on the interpretation of the trilobite biofacies and lithofacies features, has been elaborated by Nielsen (1992, 1995). He established the tripartite biozonal subdivision of the Volkhov Stage in the ScaniaBornholm area, where each zone is bound by distinct palaeoenvironmental changes which have been caused by major sea level events and are supposedly synchronous throughout Baltoscandia. In terms of Scandinavian trilobite zones, he reported upon the maximum transgression corresponding to the polyphemus Zone (= early Volkhov age in the East Baltic sense), a major regression in the simon phase (early middle Volkhov), a developing transgression and deep-water conditions beginning from the boundary of the limbata Zone (late middle Volkhov), and a regression culminating at the beginning of the Hunderum age (early Kunda age). According to this interpretation two transgressive cycles occurred during Volkhov age, which was not the opinion of Lamansky (1905) and Männil (1966).

Our data show that the highest values of the quartz/K-feldspar ratio are tied to the Püstakkiht in the lower part of the Toila Fm. This surface very likely marks the level of a most prominent regression event in the study area and neighbouring regions which is similarly interpreted in different reconstructions (Männil, 1966; Nielsen, 1995). The lowering of the erosional base was probably caused by a eustatic sea level change, judging by the extensive territory where the marker horizon can be recognized. The present data reveal simultaneous changes in the composition of the terrigenous influx.

Above the Püstakkiht the ratio of quartz to K-feldspar decreases rather smoothly towards the top of the Volkhov Stage. This general trend may be related to the circumstance that older quartz-rich sediments were already covered by carbonates and possibly explains the low quartz/K-feldspar ratio in the Volkhov/Kunda boundary beds where its new rise could be expected. Only slightly elevated values of the ratio are documented from the Pakri Fm. of the Kunda Stage, whereas in the underlying strata (Sillaoru Fm., Lahepera Mb. of the Toila Fm.) the values are close to the base line of the curve. However, some minor 
"quartz peaks" are recorded in older strata in the Saka section (Fig. 2). They cooccur with the faunal changes and some discontinuities (Meidla \& Ainsaar, 1996), but have no analogues in the Harku section.

The ostracode diversity data could be also interpreted in respect of sea level changes, based on Siveter (1984) and van Harten (1986). According to the facies models for the Ordovician Palaeobasin of Baltoscandia (Nestor, 1990), the Volkhov age sedimentation in northern Estonia has been suggested to have taken place in the upper ramp conditions. In this part of the basin the decrease in the diversity might reflect a sea level fall. The ostracode diversity changes at Harku are in general agreement with the sea level history of the area, indicating deepening of the basin and a diversity rise in the lower part of the Volkhov Stage and a diversity fall in its uppermost part. However, in the middle Volkhov interval the diversity changes can be interpreted as contradicting the former interpretations by Lamansky (1905) and Männil (1966). The decrease in the diversity index can be considered as indicative of a high degree of environmental stress on the assemblages. This suggests a shallowing during mid-Volkhov age, which is present in the model of sea level changes proposed by Nielsen (1995).

The discussed material is summarized in Fig. 6. It displays a number of biotic and sedimentological events which probably can be recognized more widely in

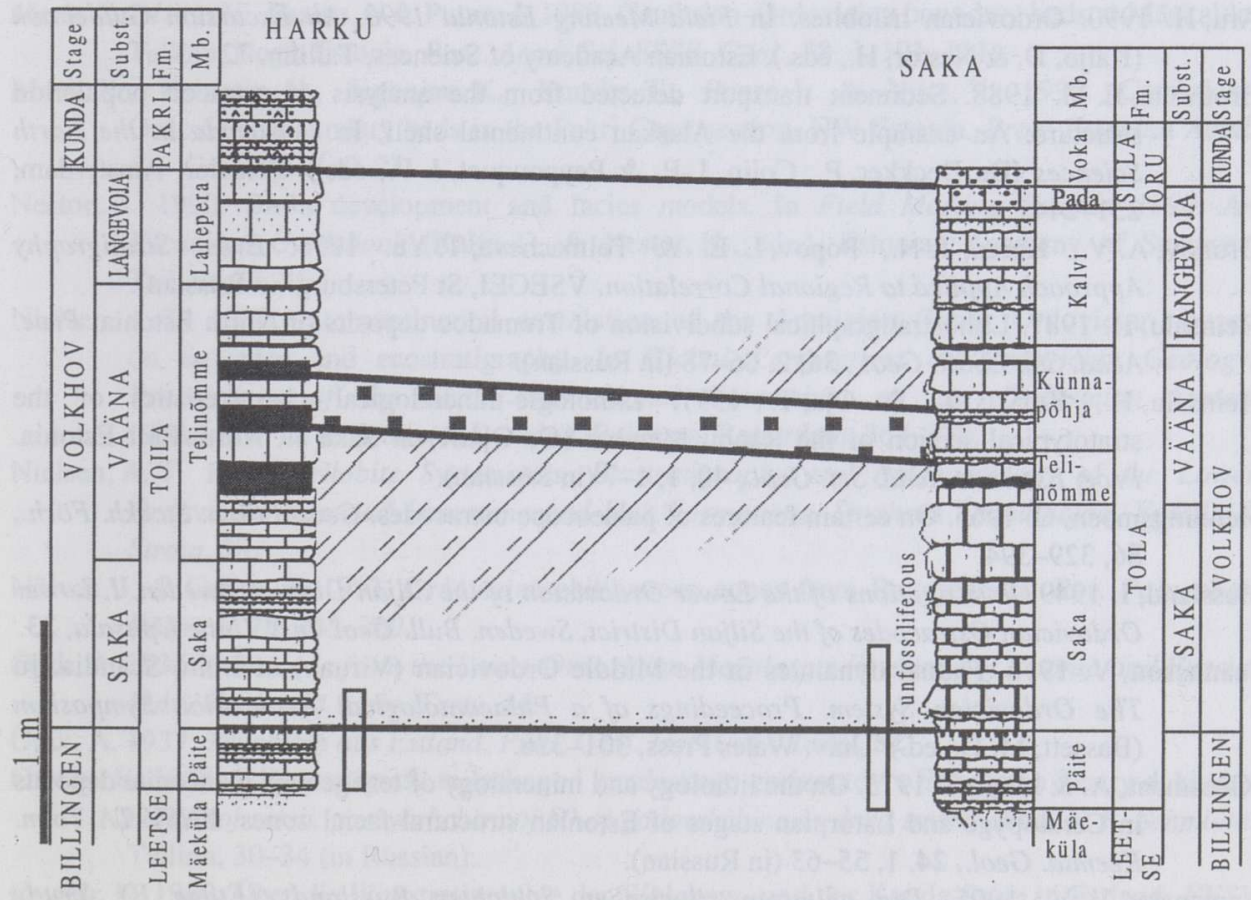

Fig. 6. Distribution of ostracode assemblages and location of elevated quartz content in the studied sections. Empty rectangles - intervals of elevated Q/Fs ratio. For legend see Figs. 2 and 4. 
North Estonia, judging by the data from two distant sections. The data remain controversial in some aspects, however, they confirm the usefulness of both mineralogical and palaeontological criteria for sea level studies.

\section{ACKNOWLEDGEMENTS}

The authors are grateful to A. Dronov (St Petersburg) and A. Nielsen (Copenhagen) for stimulating discussions at several stages of work. Special thanks are due to D. Kaljo (Tallinn) and A. Dronov for critical remarks on the manuscript. K. Kirsimäe (Tartu) assisted with XRD analyses, I. Puura (Tartu) made valuable comments on the manuscript and provided linguistic help. Sincere thanks are addressed to all these colleagues.

This paper is a contribution to the IGCP Project 410 "The Great Ordovician Biodiversification Event". The research was financially supported by the Estonian Science Foundation (grants 951 and 3011).

\section{REFERENCES}

Aru, H. 1990. Ordovician trilobites. In Field Meeting Estonia 1990. An Excursion Guidebook (Kaljo, D. \& Nestor, H., eds.). Estonian Academy of Sciences, Tallinn, 72-73.

Brouwers, E. M. 1988. Sediment transport detected from the analysis of ostracod population structure: An example from the Alaskan continental shelf. In Ostracoda in the Earth Sciences (De Deckker, P., Colin, J.-P. \& Peypouquet, J.-P., eds.). Elsevier, Amsterdam, 231-244.

Dronov, A. V., Koren, T. N., Popov, L. E. \& Tolmacheva, T. Yu. 1998. Event Stratigraphy Approach Applied to Regional Correlation. VSEGEI, St Petersburg (in Russian).

Heinsalu, H. 1987. Lithostratigraphical subdivision of Tremadoc deposits of North Estonia. Proc. Acad. Sci. ESSR. Geol., 36, 2, 66-78 (in Russian).

Heinsalu, H., Kurvits, T. \& Oja, T. 1991. Lithologic-mineralogical characteristics of the stratotypical section of the Rannu Member $\left(\epsilon_{3}-\mathrm{O}_{1} k l \mathrm{R}\right)$ at Saka II, North-East Estonia. Proc. Estonian Acad. Sci. Geol., 40, 1, 1-7 (in Russian).

Henningsmoen, G. 1965. On certain features of palaeocope ostracodes. Geol. Fören. Stockh. Förh., 86, 329-394.

Hessland, I. 1949. Investigations of the Lower Ordovician of the Siljan District, Sweden, I. Lower Ordovician Ostracodes of the Siljan District, Sweden. Bull. Geol. Inst. Univ. Uppsala, 33.

Jaanusson, V. 1976. Faunal dynamics in the Middle Ordovician (Viruan) of Balto-Scandia. In The Ordovician System. Proceedings of a Palaeontological Association Symposium (Bassett, M. G., ed.). Univ. Wales Press, 301-326.

Kleesment, A. \& Mägi, S. 1975. On the lithology and mineralogy of terrigenous glauconite deposits in Ceratopyge and Latorpian stages of Estonian structural-facial zones. ENSV TA Toim. Keemia. Geol., 24, 1, 55-63 (in Russian).

Lamansky, V. V. 1905. Die aeltesten silurischen Schichten Russlands (Etage B). Trudy Geologicheskogo Komiteta. N. S., 20. St Petersburg (in Russian).

Löfgren, A. 1995. The middle Lanna/Volkhov Stage (middle Arenig) of Sweden and its conodont fauna. Geol. Mag., 132, 6, 693-711. 
Mägi, S. 1984. A characterization of the type section of the Ontikan Subseries. Proc. Acad. Sci. ESSR. Geol., 33, 3/4, 104-112 (in Russian).

Mägi, S. 1990. Locality 1:4. Mäekalda road excavation. In Field Meeting Estonia 1990. An Excursion Guidebook (Kaljo, D. \& Nestor, H., eds.). Estonian Academy of Sciences, Tallinn, 124-127.

Männil, R. 1966. Evolution of the Baltic Basin During the Ordovician. Valgus, Tallinn (in Russian).

Männil, R. 1990. The Ordovician of Estonia. In Field Meeting Estonia 1990. An Excursion Guidebook (Kaljo, D. \& Nestor, H., eds.). Estonian Academy of Sciences, Tallinn, 11-20.

Männil, R. \& Meidla, T. 1994. The Ordovician System on the East European Platform (Estonia, Latvia, Lithuania, Byelorussia, parts of Russia, the Ukraine and Moldova). In The Ordovician System of the East European Platform and Tuva (Southeastern Russia) (Webby, B. D. \& Williams, S. H., eds.). IUGS Publication, 28, A, 1-52.

Meidla, T. 1996. Late Ordovician Ostracodes of Estonia. Fossilia Baltica, 2. Tartu University Press.

Meidla, T. 1997. Volkhov Stage. In Geology and Mineral Resources of Estonia (Raukas, A. \& Teedumäe, A., eds.). Estonian Academy Publishers, Tallinn, 61-64.

Meidla, T. \& Ainsaar, L. 1996. Evidence of Volkhovian sea-level changes in the Saka section, North Estonia. In The Third Baltic Stratigraphical Conference. Abstracts. Field Guide (Meidla, T., Puura, I., Nemliher, J., Raukas, A. \& Saarse, L., eds.). Tartu University Press, Tartu, 43-44.

Mens, K. 1984. On the mineralogy of the Ülgase Beds in Maardu district. Proc. Acad. Sci. ESSR. Geol., 33, 3/4, 96-103 (in Russian).

Mens, K. \& Pirrus, E. 1977. Stratotypes of the Cambrian Formations of Estonia. Valgus, Tallinn (in Russian).

Mens, K., Viira, V., Paalits, I. \& Puura, I. 1989. Cambrian-Ordovician boundary beds at Mäekalda, Tallinn, North Estonia. Proc. Acad. Sci. ESSR. Geol., 38, 3, 101-111.

Mens, K., Heinsalu, H., Jegonjan, K., Kurvits, T., Puura, I. \& Viira, V. 1996. CambrianOrdovician boundary beds in the Pakri Cape section, NW Estonia. Proc. Estonian Acad. Sci. Geol., 45, 1, 9-21.

Nestor, H. 1990. Basin development and facies models. In Field Meeting Estonia 1990. An Excursion Guidebook (Kaljo, D. \& Nestor, H., eds.). Estonian Academy of Sciences, Tallinn, 33-36.

Nielsen, A. T. 1992. Intercontinental correlation of the Arenigian (Early Ordovician) based on sequence and ecostratigraphy. In Global Perspectives on Ordovician Geology. Proceedings of the Sixth International Symposium on the Ordovician System (Webby, B. D. \& Laurie, J. R., eds.). Balkema, Rotterdam, 367-379.

Nielsen, A. T. 1995. Trilobite Systematics, Biostratigraphy and Palaeoecology of the Lower Ordovician Komstad Limestone and Huk Formations, Southern Scandinavia. Fossils \& Strata, 38.

Nõlvak, J. \& Grahn, Y. 1993. Ordovician chitinozoan zones from Baltoscandia. Rev. Palaeobot. Palynol., 79, 245-269.

Öpik, A. 1935. Ostracoda from the Lower Ordovician Megalaspis-limestone of Estonia and Russia. Publ. Geol. Inst. Univ. Tartu, 44.

Öpik, A. 1937. Trilobiten aus Estland. Publ. Geol. Inst. Univ. Tartu, 52.

Orviku, K. 1958. O litostratigrafii tojlaskogo i kundaskogo gorizontov v Estonii. In Tezisy dokladov nauchnoj sessii, posvyashchennoj 50-oj godovshchine so dnya smerti akad. F. B. Schmidta. Tallinn, 30-34 (in Russian).

Orviku, K. 1960. Über die lithostratigraphie der Wolchow- und der Kunda-Stufe in Estland. ENSV TA Geol. Inst. Uurimused, 5, 45-87 (in Russian).

Orviku, K. 1961. Diskontinuiteedipinnad volhovi ja kunda lademes. Geoloogiline kogumik. Tartu, $16-25$. 
Pokorny, V. 1971. The diversity of fossil ostracode communities as an indicator of palaeogeographic conditions. In Paléoécologie Ostracodes Pau 1970. Bull. Centre Rech. PauSPNA (Oertli, H. J., ed.), 5 suppl. Pau, 45-61.

Põldvere, A., Meidla, T., Bauert, G., Bauert, H. \& Stouge, S. 1998. Ordovician. In Tartu (453) Drillcore (Männik, P., ed.). Estonian Geological Sections, 1, 11-17.

Rõõmusoks, A. 1997. Ordovician trilobites. In Geology and Mineral Resources of Estonia (Raukas, A. \& Teedumäe, A., eds.). Estonian Academy Publishers, Tallinn, 234-238.

Sarv, L. 1959. Ordovician Ostracods in the Estonian S.S.R. ENSV TA Geol. Inst. Uurimused, 4 (in Russian).

Sarv, L. 1960. On the stratigraphic distribution of ostracods in the Ordovician of the Estonian S.S.R. ENSV TA Geol. Inst. Uurimused, 5, 237-244 (in Russian).

Sarv, L. 1963. New ostracods from the Ordovician of East Baltic. ENSV TA Geol. Inst. Uurimused, 13, 161-188 (in Russian).

Sarv, L. I. 1968. Development of Ordovician ostracodes of the East Baltic. In Problemy paleontologii. XXIII sessiya Mezhdunarodnogo Geologicheskogo Kongressa, 1968. Doklady sovetskikh geologov. Nedra, Moskva, 89-96 (in Russian).

Schallreuter, R. 1988. Neue Muschelkrebse aus Geschieben. Geschiebekunde aktuell, 4, 4, 101-102.

Schallreuter, R. 1989. Ein Rogösandstein-Geschiebe (Ordoviz) aus Hamburg. Geschiebekunde aktuell, 5, 1, 9-30.

Schallreuter, R. 1993. Beiträge zur Geschiebekunde Westfalens II. Ostracoden aus ordovizischen Geschieben II. Geol. Paläont. Westf., 27.

Schallreuter, R. 1994. Schwarze Orthocerenkalkgeschiebe. Geschiebekunde aktuell, 10, 8/9, 491-540.

Schmidt, F. 1879. Vzglyad" na novejshee sostoyanie nashikh poznanij o silurijskoj sisteme S.-Peterburgskoj i Éstlyandskoj gubernij i ostrova Ézelya. Trudy Sankt-Peterburgskago obshchestva estestvoispytatelej, 10, $42-48$ (in Russian).

Schmidt, F. 1881. Revision der ostbaltischen silurischen Trilobiten nebst geognostischer Übersicht des ostbaltischen Silurgebiets. Abt. I. Phacopiden, Cheiruriden und Encrinuriden. Mém. Acad. Sci. St.-Pétersb., sér. VII, XXX, 1.

Sidaravičiene, N. 1992. Ostrakody ordovika Litvy. LitNIGRI, Vilnius (in Russian).

Sidaravičiene, N. 1996. Lietuvos ordoviko ostrakodai, biostratigrafija. Geologijos Institutas, Vilnius.

Siveter, D. 1984. Habitats and modes of life of Silurian ostracodes. Spec. Pap. Palaeontol., 32, 71-85.

Stouge, S. 1989. Lower Ordovician (Ontikan) conodont biostratigraphy in Scandinavia. Proc. Acad. Sci. ESSR. Geol., 38, 2, 68-72.

Thorslund, P. 1940. On the Chasmops Series of Jemtland and Södermanland (Tvären). Sver. Geol. Unders., Ser. C, 436.

Tjernvik, T. 1956. On the Early Ordovician of Sweden. Stratigraphy and Fauna. Bull. Geol. Inst. Univ. Uppsala, 36.

Tjernvik, T. 1980. The Latorp and Lanna-Volkhov Stage \& taxonomic section. In Tjernvik, T. \& Johansson, J. V. Description of the upper portion of the drill-core from Finngrundet in the South Bothnian Bay. Bull. Geol. Inst. Univ. Uppsala N. S., 8, 173-204.

Torsvik, T. H., Smethurst, M. A., Meert, J. G., van der Voo, R., McKerrow, W. S., Brasier, M. D., Sturt, B. A. \& Walderhaug, H. J. 1996. Continental break-up and collision in the Neoproterozoic and Palaeozoic - A tale of Baltica and Laurentia. Earth-Science Rev., 40, 229-258.

Ulst, R. Zh., Gailite, L. K. \& Yakovleva, V. I. 1982. Ordovik Latvii. Zinatne, Riga (in Russian).

van Harten, D. 1986. Ostracode options in sea-level studies. In Sea-level Research: A Manual for the Collection and Evaluation of Data (van de Plassche, O., ed.). Geo Books, Norwich, 489-501.

Viira, V. 1974. Konodonty ordovika Pribaltiki. Valgus, Tallinn (in Russian).

Watkins, R. 1979. Benthic community organization in the Ludlow Series of the Welsh Borderland. Bull. British Mus. (Nat. Hist.), Geol. Series, 31, 3, 175-280. 


\title{
Tõnu MEIDLA, Leho AINSAAR ja Oive TINN
}

Ostrakoodide mitmekesisuse ja karbonaatkivimite lahustumatu jäägi mineraalse koosseisu muutuste uurimise eesmärk oli keskkonna- ja biosündmuste dokumenteerimine Volhovi lademe läbilõikes Põhja-Eestis. Olulisemad biosündmused on seotud lademe basaalse osaga ja keskosaga. Kõrgemaid kvartsi/kaaliumpäevakivi suhte väärtusi Volhovi-ealiste karbonaatkivimite lahustumatus jäägis tõlgendatakse viitena perioodilisele ulatuslikule kambriumi-varaordoviitsiumi terrigeensete setendite kulutamisele ja ümbersettimisele. Materjali on analüüsitud meretaseme kõikumise erinevate mudelite kontekstis.

\section{ВОЛХОВСКИЙ ГОРИЗОНТ В СЕВЕРНОЙ ЭСТОНИИ И КОЛЕБАНИЯ УРОВНЯ МОРЯ}

\author{
ТЫну МЕЙДЛА, Лехо АЙНСААР и ОЙве ТИНН
}

Изучены остракоды и нерастворимый остаток карбонатных пород в целях выявления биотических и экологических событий в разрезе волховского горизонта в Северной Эстонии. Важнейшие биотические события связаны с нижней и средней частями волховского горизонта. Повышенные значения отношения кварца и К-полевого шпата в нерастворимом остатке волховских карбонатов интерпретируются как доказательство периодичной повышенной эрозии и переотложения кембрийских и раннеордовикских терригенных формаций. Данные дискутируются в контексте разных моделей колебания уровня моря. 